\title{
Resistance to Nisin and Production of Nisin-Inactivating Enzymes by Several Bacillus Species
}

\author{
By B. JAR VIS \\ National College of Food Technology (University of Reading), \\ Weybridge, Surrey
}

(Accepted for publication 1 November 1966)

\begin{abstract}
SUMMARY
The resistance to nisin was examined for the vegetative forms and the endospores of 14 strains of 9 species of the genus Bacillus. Bacilli, endospores and culture filtrates were tested for ability to inactivate nisin. Marked antinisin activity was detected in extracts of bacilli and endospores of organisms which have a lytic mechanism for rupture of the spore coat (type L); little or no activity was observed in extracts from organisms which rupture the spore coat mechanically (type M). No significant extracellular activity was detected, except after the autolysis of bacilli. When organisms were cultivated in the presence of nisin (50 Reading units/ml.; Berridge, 1949) the yield of organisms and the specific activity of the extracts was decreased; evidence to explain these observations is presented. No quantitative correlation was observed between the production of anti-nisin activity and the resistance of vegetative forms.

The anti-nisin activity of cell-free extracts of bacilli of two species (Bacillus cereus and $B$. polymyxa) was studied further; there was evidence that the activity was probably enzymic. A preliminary study of the properties of the enzymes from these organisms was made. It was found that the anti-nisin enzymes of two strains of $B$. cereus differed from the lytic enzymes previously described (Strange \& Dark, 1957a,b). The anti-nisin enzymes had no effect on polymyxin, gramicidin or bactracin but inactivated subtilin. Proteolytic activity was not observed in the preparations.
\end{abstract}

\section{INTRODUCTION}

Nisinase, an enzyme capable of destroying the polypeptide antibiotic nisin, has been shown in nisin-resistant strains of streptococci (Alifax \& Chevalier, 1962; Galesloot, 1956; Lipinska \& Strzalkowska, 1959), and in strains of Staphylococcus aureus (Carlson \& Bauer, 1957). In a restricted range of substrate specificity tests the nisinase of Streptococcus thermophilus was shown to be active against nisin but not against some other antibodies tested (Alifax \& Chevalier, 1962). Gould \& Hurst (1962) and Gould (1964) showed that the nisin resistance of endospores of certain Bacillus species was related to the post-germination mechanism for the rupture of the spore-coat. They showed that spores which had a lytic mechanism for rupture of the spore-coat (type L) contained a nisin-inactivator which was not detectable in spores which ruptured the spore-coat mechanically (type $\mathrm{M}$ ), and they showed that type $\mathrm{L}$ spores had a higher resistance to nisin than had type $M$ spores. They also showed that there was little difference in the resistance of spores and vegetative forms of type L organisms, but that the vegetative forms of spore type $M$ organisms were often 20 times 
more resistant than were the corresponding endospores. The present paper describes work to determine whether the natural resistance of vegetative forms of species of Bacillus is related to the production of constitutive or inducible enzymes capable of inactivating nisin. Factors which affect the production of the nisin-inactivating enzymes of Bacillus cereus and B. polymyxa, and some of the properties of these enzymes, were examined.

\section{METHODS}

Organisms. The species and strains of the organisms used in this work are given in Table 1. A culture of Bacillus cereus (Px) was also used in some experiments. All the organisms conformed to the descriptions given by Smith, Gordon \& Clark (1952). Stock cultures were maintained on nutrient agar (Oxoid no. 1) at $4^{\circ}$ and were subcultured monthly.

Resistance of organisms to nisin. The resistance of organisms to nisin was determined by plating $0.02 \mathrm{ml}$. of a standardized washed suspension of vegetative forms, or of heat-shocked ( $85^{\circ}$ for $15 \mathrm{~min}$ ) endospores, on the air-dried surface of plates of glucose tryptone agar (pH 6.8) containing from 0 to 100 Reading units (r.u.) nisin/ml. (For Reading units, see later; Berridge, 1949). The highest concentration of nisin which permitted macroscopic growth after incubation for $18 \mathrm{hr}$ was taken as the measure of resistance of the organism. All tests, which were repeated on three separate occasions, were done in duplicate and the mean degree of resistance recorded.

Production of cell-free extracts. Conical flasks (11.), each containing $250 \mathrm{ml}$. Tryptone Soya (TS) broth (Oxoid; pH 6.8) were inoculated to $1 \%(\mathrm{v} / \mathrm{v})$ with a $6 \mathrm{hr}$ shake culture of the organism in TS broth. The flasks were shaken for $18 \mathrm{hr}$ at the appropriate temperature (Table 2) in a water bath. Organisms were harvested by centrifugation, washed by centrifugation four times, each with $50 \mathrm{ml}$. sterile buffer $\left(0.1 \mathrm{M}\right.$-citric acid $+0.2 \mathrm{M}-\mathrm{Na}_{2} \mathrm{HPO}_{4} ; \mathrm{pH} 7 \cdot 0 ;$ McIlvaine, 1921), and were then suspended in $10 \mathrm{ml}$. of the same buffer to give a thick suspension. Acetone powders were prepared at $-20^{\circ}$ according to the method of Gunsalus (1954). The yield of acetone powder was determined for each organism and a $0.5 \%$ (w/v) suspension of the powder in Mcllvaine's buffer ( $\mathrm{pH} 7 \cdot 0$ ) was shaken in a stoppered flask for 5 days at $2^{\circ}$ on a Microid flask shaker. Prolonged extraction was required to obtain an active extract from the acetone powders. Insoluble material was then removed by centrifugation at $20,000 \mathrm{~g}$ for $15 \mathrm{~min}$. and the supernatant fluid used to assay its anti-nisin activity.

When organisms were grown in the presence of nisin, the cultures were incubated for $6 \mathrm{hr}$ before adding to each flask $2.5 \mathrm{ml}$. of a solution of $5000 \mathrm{r}$.u. nisin/ml. of $0.02 \mathrm{~N}-\mathrm{HCl}$; incubation was continued for a further $12 \mathrm{hr}$ and the organisms then harvested. Acetone powders produced from the washed organisms were extracted with buffer by the procedure outlined above.

In later experiments the acetone powder method was replaced by an autolytic one. Organisms were suspended in McIlvaine buffer (0.05 M-citric acid $+0.1 \mathrm{M}-\mathrm{Na}_{2} \mathrm{HPO}_{4}$; $\mathrm{pH} 6.5$ ), to a concentration equivalent to about $50 \mathrm{mg}$. dry wt. $/ \mathrm{ml}$, and incubated for $1 \mathrm{hr}$ at $45^{\circ}$ in the presence of toluene $(2.5 \%, \mathrm{v} / \mathrm{v})$. After incubation, the autolysate was cooled to $1^{\circ}$, centrifuged at $20,000 \mathrm{~g}$ for $15 \mathrm{~min}$. and the supernatant fluid used to assay anti-nisin activity. A more active preparation was obtained by the autolytic method than by extraction of acetone-dried organisms.

Culture filtrates. The supernatant culture fluids after centrifugation of cultures to 
deposit organisms were sterilized by Seitz filtration and adjusted to $\mathrm{pH} 7.0$ by dissolving one phosphate buffer tablet (Edward Gurr Ltd.) in each $100 \mathrm{ml}$. filtrate. This solution was then used for the determination of anti-nisin activity.

Preparation of spore extracts. Slopes of 'sporulation agar' (nutrient agar re-inforced with $0.1 \%$ glucose $+0.04 \%$ anhydrous $\mathrm{MgSO}_{4}$ ) in $16 \mathrm{oz}$. medical flat bottles were inoculated with $5 \mathrm{ml}$. of an $18 \mathrm{hr}$ shake culture in TS broth. The inoculum suspension was spread over the surface of the agar and the excess decanted. Slopes were incubated for 8 days, or until sporulation and lysis of the sporangia was complete. The spores were then washed from the surface with sterile distilled water, washed exhaustively with water by centrifugation, the upper layer of the pellet being discarded at each washing to remove residues of vegetative forms. Spores were extracted by shaking in a Mickle tissue disintegrator ( $\mathrm{H}$. Mickle Ltd., Gomshall, Surrey) for $2 \mathrm{hr}$ at $2^{\circ}$ with Mcllvaine buffer (pH 7.0) in the presence of ballotini beads (grade 14). The ballotini and spore debris were removed by filtration through sintered glass filters (no. 2 porosity) followed by centrifugation at $20,000 \mathrm{~g}$ for $15 \mathrm{~min}$. The supernatant fluid was used for the assay of its anti-nisin activity.

Microscopic examinations. TS broth cultures of the organisms were stained with aqueous fuchsin (Smith et al. 1952) and examined for the presence of endospores. The extent of sporulation was determined by counting the number of sporulated organisms per field of view and relating this to the total number of organisms per field. Release of mature endospores was observed by phase-contrast microscopy.

Assay of anti-nisin activity. Anti-nisin activity was measured by incubating suitable volumes $(0 \cdot 1-4.0 \mathrm{ml}$.) of cell-free extract, or of culture filtrate, with $1 \mathrm{ml}$. of a solution of nisin $(5000$ r.u. $/ \mathrm{ml} .0 .02 \mathrm{~N}-\mathrm{HCl})$, the total volume being adjusted to $9 \cdot 0 \mathrm{ml}$. with McIlvaine buffer ( $\mathrm{pH}$ 7.0). Controls were prepared at the same time and consisted of buffered substrate alone, or of buffered substrate with autoclaved cell-free extract equal in volume to the extract used in the test. The incubated reaction mixtures were at $\mathrm{pH} 7 \cdot 0 \pm 0 \cdot 1$. Samples $(0 \cdot 9 \mathrm{ml}$.) removed immediately after preparation of the reaction mixture and at intervals during the incubation period of $6 \mathrm{hr}$ were pipetted into $0.1 \mathrm{ml}$. of $2 \mathrm{~N}-\mathrm{HCl}$ to bring to $\mathrm{pH} 2 \cdot 0$. After mixing, the acidified samples were heated for $5 \mathrm{~min}$. in a water bath at $100^{\circ}$ to obtain maximal recovery of nisin, cooled and stored at $2^{\circ}$ until required for assay of residual nisin.

The acidified samples were diluted in $0.02 \mathrm{~N}-\mathrm{HCl}$ by using a 'Clinical Diluter' (Camlab Glass Ltd., Cambridge) to give solutions containing between 2.0 and 10.0 r.u. nisin/ml. Residual nisin was determined by the agar diffusion method of Tramer \& Fowler (1964), by using large glass plates (12 in. $\times 12$ in. $(30.5 \mathrm{~cm}$.) internal dimensions; each plate required $300 \mathrm{ml}$. medium to give a depth of about $3 \mathrm{~mm}$.). Standard solutions and test samples were dispensed on each plate, four wells being used for each sample, to allow for variation in diffusion of the antibiotic; the plates were incubated for $18 \mathrm{hr}$ at $30^{\circ}$.

The diameters of the zones of inhibition were measured after projection (Jarvis, 1966) and the concentrations of residual nisin computed from the graph of projected zone diameter plotted against $\log _{10}$ nisin concentration in the standards. The quantity of nisin destroyed was calculated from the difference between the nisin concentrations before and after incubation of the test samples, due allowance being made for loss of activity of the nisin in the controls (about $10 \%$ ) and for the dilution factor. This method of assay was reproducible to within $\pm 10 \%$. 
Units of activity of nisin and of the enzymes. The unit of activity of nisin as defined by Tramer \& Fowler (1964) is the activity exhibited by $1.0 \mu \mathrm{g}$. of a standard batch of commercial nisin (Nisaplin; Aplin and Barrett Ltd., Trowbridge, Wilts.) and is reputed to be equivalent to the previously defined Reading unit (r.u.: Berridge, 1949). The unit of enzymic activity (e.u.) is an arbitrary unit defined as that amount of enzyme which will inactivate 1000 r.u. nisin in $6 \mathrm{hr}$ at $\mathrm{pH} 7.0$ and at the optimum temperature for the organism from which the enzyme was extracted. It is not possible at this stage to define the activity more precisely, as recommended by the Commission on Enzymes of the International Union of Biochemistry (Report, 1961).

Growth curves. The extinction of TS broth shake-flask cultures was determined after various periods of incubation and growth curves plotted against time. Where necessary, the culture was diluted in TS broth; extinction measurements were made with an EEL Spectra absorptiometer (Evans Electroselenium Ltd., Halstead, Essex) at $650 \mathrm{~m} \mu$ with a $10 \mathrm{~mm}$. cuvette.

Dialysis of cell-free extracts. Visking dialysis tubing (Hudes Merchandising Co. Ltd., London) was used for dialysis experiments. Before use the tubing was boiled for $30 \mathrm{~min}$. in glass-distilled water and rinsed in six changes of glass-distilled water. Cellfree extracts in McIlvaine buffer ( $\mathrm{pH} \mathrm{7.0)}$ were dialysed against isomolar buffer or distilled water for up to $48 \mathrm{hr}$ at $2^{\circ}$. The dialysis residue was used for assays of enzyme in the presence of buffered solutions of cations.

Specificity of action of enzyme preparations. The enzyme preparations were tested for ability to hydrolyse casein by pipetting buffered cell-free extract into wells cut in plates of casein agar $\left(10 \mathrm{ml}\right.$. melted $3 \%(\mathrm{w} / \mathrm{v})$, Ionagar no. 2 , tempered to $50^{\circ}$, mixed with an equal volume of tempered skim milk at the same temperature, poured into Petri dishes and allowed to set). After incubation at $30^{\circ}$ for $18 \mathrm{hr}$ the plates were examined for cleared zones around the wells.

Activity against bovine serum albumen (Armour Pharmaceutical Co. Ltd., Eastbourne, Sussex) and against gelatin was assessed by formol titration. The reaction mixtures consisted of $1.0 \mathrm{ml}$. cell-free extract and $50 \mathrm{ml} .1 \%(\mathrm{w} / \mathrm{v})$ protein solution adjusted to $\mathrm{pH} 7 \cdot 0$. After incubation for periods up to $72 \mathrm{hr}$, samples were assayed for increase in formol titration. Substrate and enzyme controls were run simultaneously and all reactions were compared with the activity of $1.0 \mathrm{ml}$. of a solution of Bactotrypsin $1 \%$ (Difco Ltd.).

The renneting action of buffered cell-free extracts $(1.0 \mathrm{ml}$.) was determined against $10 \mathrm{ml}$. freshly reconstituted skim milk in the presence of $0.02 \mathrm{M}-\mathrm{CaCl}_{2}$, at $\mathrm{pH} 6.0$ and 7.0. Controls of substrate and of substrate + rennet were incubated simultaneously at $30^{\circ}$.

The preparations were tested against the polypeptide antibiotics bacitracin, polymyxin (both from the Wellcome Research Laboratories, Beckenham, Kent), gramicidin (Koch-Light Laboratories Ltd., Colnbrook, Bucks) and subtilin (kindly supplied by Dr J. C. Lewis, U.S.D.A., Albany 10, California, U.S.A.). Residual antibiotic was determined on the pre- and post-incubation samples by agar diffusion assay against Micrococcus flavus.

Cell-free extracts of Bacillus cereus (PX and NCIB 3329) were assayed against isolated cell-wall preparations which had been made from vegetative forms of the same organisms as described by Salton \& Horne (1951), and freeze dried. Lytic activity was measured by observing the decrease in extinction of a cell-wall suspension when 
incubated with enzyme preparation in the presence of $\mathrm{Co}^{2+}$ (Strange \& Dark, 1957b). Although this method gave an indication of lytic activity it was not very satisfactory.

Electrophoresis of cell-free extracts. Samples of buffered cell-free extract were freezedried and redissolved in $1 / 10$ the original volume of distilled water. Electrophoresis was done on cellulose acetate, $12 \mathrm{~cm} . \times 2 \cdot 5 \mathrm{~cm}$. (Oxoid, Ltd.) in a Kohn horizontal electrophoresis tank (Shandon Scientific Co. Ltd., London) with barbitone buffer $(\mathrm{pH} 8.6, \lambda=0.05)$, acetate buffer $(\mathrm{pH} 4.0, \lambda=0.05)$ and tris-EDTA buffer $(\mathrm{pH} 7 \cdot 0$; Smith, 1960). For all experiments a potential of $2.5 \mathrm{~V} . / \mathrm{cm}$. strip-length was used. Protein bands were stained with Ponceau S according to the method of Kohn (1958).

\section{RESULTS}

Resistance to nisin of vegetative forms and endospores of Bacillus species

The mean measures of resistance are presented in Table 1. The first four organisms have an enzymic mechanism for post-germination rupture of the spore-coat (type L) and these endospores were more resistant to nisin than were the endospores of the other organisms, which split the spore-coat mechanically (type M). There was little difference between the degrees of resistance of the vegetative forms of the two groups, with the exception of the thermophilic Bacillus stearothermophilus which was highly sensitive to nisin. Although the degrees of resistance for spore coat-splitting (type M) strains were slightly higher than those reported by Gould (1964) the results show the same general pattern. The difference was probably the result of differences in technique.

Table 1. Resistance of Bacillus species to nisin

\begin{tabular}{|c|c|c|c|}
\hline \multirow[b]{2}{*}{ Organism } & \multirow[b]{2}{*}{ Strain } & \multicolumn{2}{|c|}{$\begin{array}{l}\text { Minimum inhibitory concentratio } \\
\text { of nisin (r.u./ml.) to prevent } \\
\text { colony formation by }\end{array}$} \\
\hline & & $\begin{array}{l}\text { Vegetative } \\
\text { inoculum }\end{array}$ & $\begin{array}{c}\text { Spore } \\
\text { inoculum }\end{array}$ \\
\hline $\begin{array}{l}\text { Spore coat type } \mathrm{L}^{*} \\
\text { Bacillus cereus } \\
\text { B. cereus } \text { var. mycoides } \\
\text { B. polymyxa } \\
\text { B. megaterium }\end{array}$ & $\begin{array}{l}\text { NCIB } 3329 \\
\text { NCIB } 7586 \\
\text { NCIB } 8094 \\
\text { NCIB } 6005\end{array}$ & $\begin{array}{r}>100 \\
>100 \\
>100 \\
75\end{array}$ & $\begin{array}{r}100 \\
75 \\
50 \\
25\end{array}$ \\
\hline $\begin{array}{l}\text { Spore coat type } \mathrm{M} \dagger \\
\text { B. subtilis } \\
\text { B. subtilis } \\
\text { B. subtilis } \\
\text { B. subtilis } \\
\text { B. licheniformis } \\
\text { B. licheniformis } \\
\text { B. coagulans } \\
\text { B. pumilis } \\
\text { B. stearothermophilus } \\
\text { B. stearothermophilus }\end{array}$ & $\begin{array}{l}\text { CN } 665 \\
\text { NCIB } 8739 \\
\text { NCIB } 8057 \\
\text { NCFT } 129 \\
\text { NCIB } 8061 \\
\text { NCFT } 128 \\
\text { NCTC } 3992 \\
\text { NCFT } 127 \\
\text { NCIB } 8157 \\
\text { NCIB } 8224\end{array}$ & $\begin{array}{r}>100 \\
75 \\
>100 \\
100 \\
>100 \\
>100 \\
>100 \\
>100 \\
3 \\
6\end{array}$ & $\begin{array}{r}6 \\
3 \\
6 \\
6 \\
13 \\
13 \\
3 \\
13 \\
<2 \\
<2\end{array}$ \\
\hline
\end{tabular}




\section{Anti-nisin activity of cell-free preparations}

Marked ability to inactivate nisin was detected in extracts of type L spores, but none was observed in extracts of type $M$ spores. The anti-nisin activity of cell-free extracts of vegetative forms grown in the presence and absence of nisin $(50 \mathrm{r} . \mathrm{u} . / \mathrm{ml}$. medium) are presented in Table 2 . In most instances decreased yields of acetone-dried organisms and smaller specific activities of the extracts resulted from cultivation of the organisms in the presence of nisin. Experiments were later made to explain these observations (see below).

Extracts of nisin-grown organisms from one strain of Bacillus subtilis (NCIB 8057) exhibited greater anti-nisin activity than did extracts of the same organisms cultivated in nisin-free medium. Carlson \& Bauer (1957) showed that the resistance to nisin of a strain of $B$. subtilis was increased by serial culture in the presence of nisin. It is possible, therefore, that the artificially developed resistance of $B$. subtillis was dependent upon induction of a specific 'nisinase' as is the case with Streptococcus thermophilus (Alifax \& Chevalier, 1962) and with Staphylococcus aureus (Carlson \& Bauer, 1957).

Extracellular activity was only observed in filtrates of $18 \mathrm{hr}$ cultures of Bacillus polymyxa $(0.1 \mathrm{e}$.u. $/ \mathrm{ml}$.) and of two strains of $B$. subtilis $(0.1$ and $0.4 \mathrm{e}$.u. $/ \mathrm{ml}$. for strains CN 665 and NCIB 8075, respectively). However, some activity was shown by filtrates of 2-day to 8-day cultures of B. cereus (NCIB 3329), B. cereus var. mycoides and B. polymyxa; this is considered to have been due to liberation of intracellular enzymes on autolysis of the organisms. The activity in the filtrates of $B$. subtilis may also have resulted from autolysis, but was possibly due to the production of subtilopeptidase, an extracellular proteolytic enzyme of certain strains of $B$. subtilis (Güntelberg \& Ottesen, 1952), which was shown to inactivate nisin (Jarvis, unpublished observation); 100 i.u. subtilopeptidase (B.D.H. Ltd., Poole, Dorset) inactivated about 150 r.u. nisin in $6 \mathrm{hr}$ at $\mathrm{pH} \mathrm{7 \cdot 0}$. Since all the organisms used in this work showed marked proteolytic activity on laboratory media and since proteolytic activity was observed in many of the culture filtrates this suggests that nisin is unaffected by the extracellular proteolytic enzymes of many Bacillus species.

\section{Effect of nisin on the vegetative forms of Bacillus}

Growth curves were prepared with cultures of Bacillus cereus (NCIB 3329), B. polymyxa and B. subtilis (NCIB 8057). The curves in Fig. 1 are typical of those obtained. The addition of nisin to cultures in the lag phase resulted in a prolongation of that phase, whilst addition of nisin during the logarithmic phase caused rapid lysis of the organisms and the introduction of a prolonged secondary lag phase. The degree of lysis and the duration of the secondary lag phase were dependent upon the concentration of nisin added (Fig. 2). After the initial inhibition the cultures grew normally except that an increased tendency to form chains was frequently observed. The nisin resistance of the organisms was not apparently increased. When nisin was added at the end of the logarithmic phase (Fig. 1), little change occurred either in the concentration of the organisms or in the rate of growth. This may have been merely a reflexion of the greater numbers of organisms present at this time. These results are similar to those reported for Clostridium butyricum (Ramseier, 1960) and for Staphylococcus aureus (Carlson \& Bauer, 1957). 


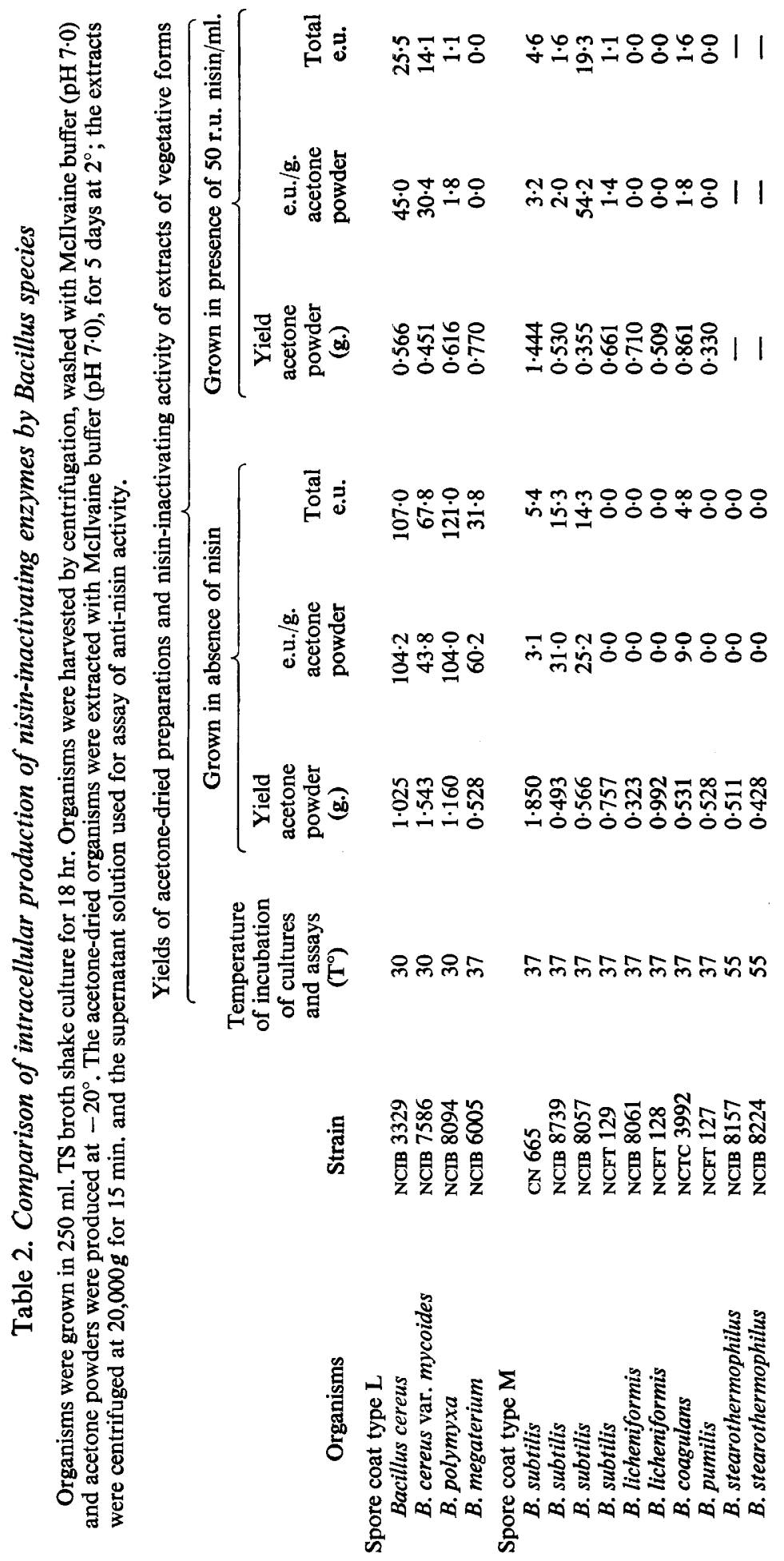




\section{Production of the nisin-inactivating enzyme}

The anti-nisin activity of Bacillus cereus (NCIB 3329 and PX) and B. polymyxa was determined for extracts of organisms taken at different stages of growth. No activity was detected until the beginning of sporulation, and the activity reached a peak shortly before the liberation of the endospores (Table 3 ). These results suggest a similarity between the anti-nisin enzyme and the lytic enzymes previously described by Strange \& Dark (1957a,b). Gould \& Hurst (1962) showed that the crude extract from endospores
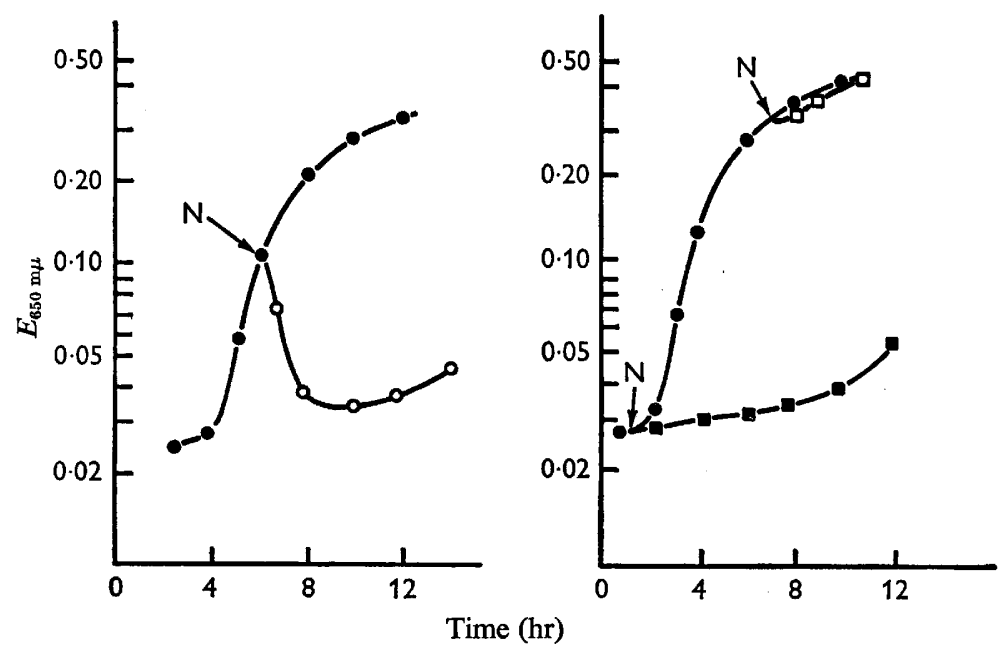

Fig. 1. The effect of nisin on vegetative Bacillus cereus. The extinction of TS broth shake cultures was determined at $650 \mathrm{~m} \mu$ using a $10 \mathrm{~mm}$. cuvette. Nisin was added (N), to a final concentration of $50 \mathrm{r.u} . / \mathrm{ml}$. medium, to cultures in the lag phase (西), the logarithmic phase $(\mathrm{O}-\mathrm{O})$ and at the end of the logarithmic phase $(\square-\square)$; a nisin-free control (O-O) was incubated simultaneously.

Table 3. Production of nisin-inactivating enzyme by Bacillus cereus (PX) at different stages of growth

The organisms were grown in TS broth shake culture at $30^{\circ}$. Samples were removed at intervals and extracts were prepared by autolysis of washed organisms at $45^{\circ}, \mathrm{pH} 6.5$ for $1 \mathrm{hr}$. The dry wt. of organisms was determined by drying suitable samples of the suspension of organisms in vacuum at $70^{\circ}$ for $18 \mathrm{hr}$, and the extent of sporulation was determined by microscopy.

Time of incubation (hr)

6 18 24 28
State of organisms Non-sporulating vegetative Sporulation begun Sporulation $>90 \%$ complete Spore-liberation begun
Nisin-inactivating activity of cell-free extract (e.u./g. dry wt. organism)

$$
\begin{array}{r}
<1 \\
28 \\
1,747 \\
1,828
\end{array}
$$

of B. cereus (PX) was active against nisin and Gould \& Hitchins (1965) showed that the Strange \& Dark enzyme isolated from spores of $B$. cereus (PX) was able to initiate germination in suitably primed spores. 


\section{Comparison of the nisin-inactivating and the lytic enzymes of Bacillus cereus}

Cell-free extracts of organisms from sporulating cultures of Bacillus cereus (NCIB 3329 and PX) were prepared by autolysis at pH 5.5 and pH 7.0 (Strange \& Dark, 1957 b) and by buffer extraction of acetone-dried organisms. The results obtained (Table 4) show that although the crude cell-free extracts were active against isolated cell walls and nisin, the partial purification procedure of Strange \& Dark (1957b) resulted in total inactivation of the nisin-inactivating enzyme, whilst the wall lytic enzymes remained active. However, the method used for assay of lytic activity was not very satisfactory because of precipitation in the blanks and the low relative activity of the preparations as compared to those reported by Strange \& Dark $(1957 a, b)$.

Table 4. Comparison of nisin-inactivating and cell-wall lytic enzymes of Bacillus cereus

Extracts of sporulating organisms grown in TS broth shake culture were prepared by buffer extraction of acetone-dried organisms and by autolysis of organisms at pH 5.5 and pH 7.0 (Strange \& Dark, 1957b). The crude extracts were partially purified by precipitation at pH 3.0 (Strange \& Dark, 1957b).

\begin{tabular}{|c|c|c|c|c|c|c|c|}
\hline & & & & Effect* of & $m e$ & & \\
\hline & & Isolated & 11 walls o & B. cereus & & Nisin $†$ & \\
\hline $\begin{array}{l}\text { Method of } \\
\text { extraction }\end{array}$ & $\begin{array}{c}\text { Extraction } \\
\text { at pH }\end{array}$ & $\begin{array}{l}\text { Crude } \\
\text { extract }\end{array}$ & $\begin{array}{l}\text { pH 3f } \\
\text { soluble } \\
\text { fraction }\end{array}$ & $\begin{array}{c}\mathrm{pH} 3 \dagger \\
\text { insoluble } \\
\text { fraction }\end{array}$ & $\begin{array}{r}\text { Crude } \\
\text { extract }\end{array}$ & $\begin{array}{c}\text { pH } 3 \\
\text { soluble } \\
\text { fraction }\end{array}$ & $\begin{array}{l}\text { pH } 3 \\
\text { insoluble } \\
\text { fraction }\end{array}$ \\
\hline Autolysis $\S$ & $5 \cdot 5$ & ++ & ++ & + & + & - & - \\
\hline Autolysis & $7 \cdot 0$ & + & + & + & +++ & - & - \\
\hline Acetone powder & $5 \cdot 5$ & ++ & + & + & + & - & - \\
\hline Acetone powder & $7 \cdot 0$ & + & + & + & +++ & - & - \\
\hline $\begin{array}{l}* \text { Activity scor } \\
\dagger \text { Assayed at } p \\
\ddagger \text { Assayed at } p \\
\S \text { Method of a } \\
\text { McIlvaine buff }\end{array}$ & $\begin{array}{l}1 \text { as highly a } \\
7.0 ; \text { (Strang } \\
4.0 ; \text { (Strang } \\
\text { olysis: suspe } \\
+2.5 \% \text { (v/ }\end{array}$ & $\begin{array}{l}\text { ive, }+ \\
\& \text { Dar } \\
\& \text { Dar } \\
\text { sion of } \\
\text { toluen }\end{array}$ & $\begin{array}{l}\text {; active, } \\
957 b) . \\
957 b \text { ) } \\
\text { nisms in }\end{array}$ & ter $(a b c$ & tive, & lactive, & \\
\hline
\end{tabular}

The crude cell-free extracts of vegetative Bacillus cereus (NCIB 3329) and B. polymyxa have been shown to be unable to initiate germination of 'primed' spores (Dr G. W. Gould, personal communication, 1966), whilst a preparation of sporegerminating enzyme from B. cereus (PX) (Gould \& Hitchins, 1965) was unable to inactivate nisin.

\section{Evidence that the inactivation of nisin by cell-free extracts of Bacillus cereus and B. polymyxa is enzymic}

In the experiments already described, it was assumed that inactivation of nisin resulted from enzymic action. Some experiments were made to confirm this assumption. The degree of anti-nisin activity was dependent upon the volume of cell-free extract used and upon the time of incubation (Fig. 3). After incubation for $1 \mathrm{hr}$ the amount of nisin inactivated was directly proportional to the volume of extract used but after incubation for $6 \mathrm{hr}$ the rate of reaction had decreased considerably and the decrease in nisin activity was no longer directly proportional to the concentration of 
cell-free extract. Where very dilute enzyme preparations were used, e.g. $0 \cdot 1-1 \cdot 0 \mathrm{ml}$. of a $1 / 100$ dilution, the inactivation was proportional to the volume of extract, even after incubation for $18 \mathrm{hr}$. These observations suggest that the activities reported above in Table 2 may have underestimated the potential activity of the more active preparations. The initial rate of inactivation, obtained from the slope of the tangent to the reaction curve at time $0 \mathrm{hr}$, is directly proportional to the volume of extract used (Fig. 4). No attempt has been made to determine Michaelis constants for the enzymes.

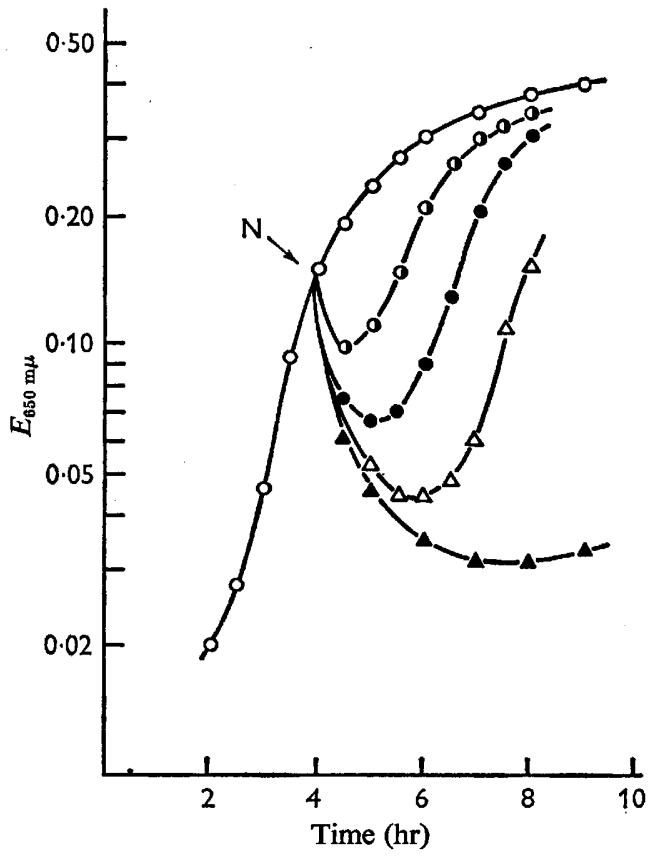

Fig. 2

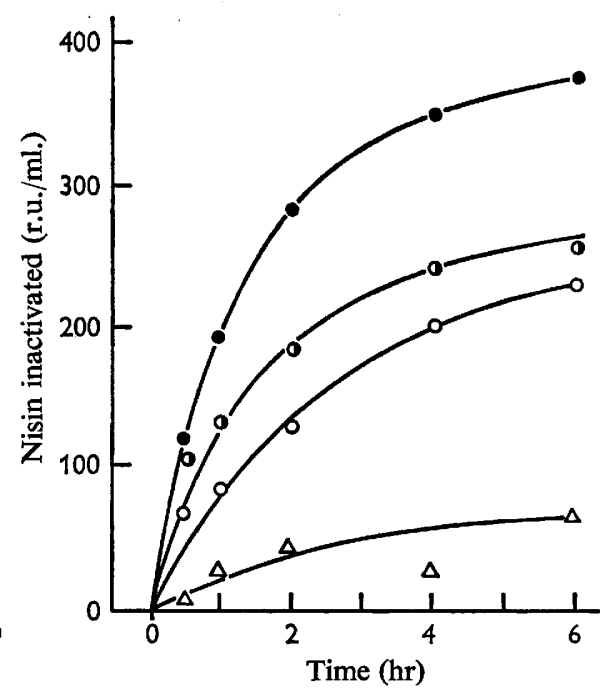

Fig. 3

Fig. 2. The effect of nisin concentration on the lysis of logarithmic phase organisms of Bacillus cereus. Different volumes of a solution of nisin in $0.02 \mathrm{~N}-\mathrm{HCl}$ were added $(\mathrm{N})$ to logarithmic phase organisms of $B$. cereus ( $\mathrm{NCIB} 3329$ ) in TS broth shake culture, to a final concentration of 50 r.u. $/ \mathrm{ml}$. $(\Delta-\Delta), 25 \mathrm{r} . \mathrm{u} . / \mathrm{ml} .(\Delta-\Delta), 12.5 \mathrm{r.u} . / \mathrm{ml}$. $(\bullet-\bullet), 6.25 \mathrm{r} . \mathrm{u} . / \mathrm{ml}$. ( $-\mathrm{O})$, and 0 r.u./ml. (O-O). Extinction was determined at $650 \mathrm{~m} \mu$ using a $10 \mathrm{~mm}$. cuvette.

Fig. 3. The effect of time and volume of enzyme preparation on the inactivation of nisin by cell-free extract of Bacillus polymyxa. The reaction mixtures consisted of $1.0 \mathrm{ml}$. of a solution of nisin (5,000 r.u./ml. $0.02 \mathrm{~N}-\mathrm{HCl})$, an aliquot of buffered cell-free extract and Mcllvaine's buffer $(\mathrm{pH} 7.0)$ to $9.0 \mathrm{ml}$. The curves correspond to cell-free extract used at the following

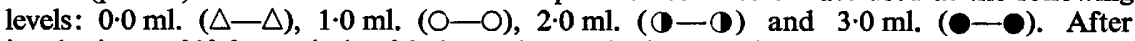
incubation at $30^{\circ}$ for periods of $0,0 \cdot 5,1,2,4$ and $6 \mathrm{hr}$, samples $(0.9 \mathrm{ml}$.) were removed and pipetted into $0.1 \mathrm{ml}$. $2 \mathrm{~N}-\mathrm{HCl}$. The acidified mixtures were boiled for $5 \mathrm{~min}$., cooled and diluted in $0.02 \mathrm{~N}-\mathrm{HCl}$ for assay of residual nisin.

The preparations were active at low enzyme: substrate ratios, on a dry-weight basis. Experiments were made with partially purified nisin as substrate. At a substrate concentration equivalent to $2 \cdot 2 \mathrm{mg}$. nisin A (40 r.u. $/ \mu \mathrm{g}$.), $93 \%$ inactivation was obtained after incubation for $24 \mathrm{hr}$ at $30^{\circ}$ and $\mathrm{pH} 7 \cdot 0$, with $0.1 \mathrm{ml} .(200 \mu \mathrm{g}$. dry wt. $/ \mathrm{ml}$.) cell-free preparation from Bacillus polymyxa. In the control series containing either 
no enzyme or heat-inactivated enzyme, only a $12 \%$ decrease of nisin activity was observed. Whilst the enzyme:substrate ratio in this experiment was only of the order of $1: 110$ it may be assumed that the partially purified nisin used as substrate contained nisin $\mathrm{A}$, together with other nisins of lower specific activity, so that the actual enzyme:substrate ratio might have been several orders lower than that reported. Marked inactivation of nisin was obtained with $B$. cereus extracts at ratios down to 1:500 (assuming nisin $\mathrm{A}$ as substrate).

The nisin-inactivating enzymes were inactivated by heating to $100^{\circ}$ for $5 \mathrm{~min}$.; treatment of the preparations at room temperature with ethanol, acetone, trichloracetic acid or sodium tungstate resulted in total loss of anti-nisin activity. These results suggest that the anti-nisin activity was dependent upon the protein moiety of the extracts.

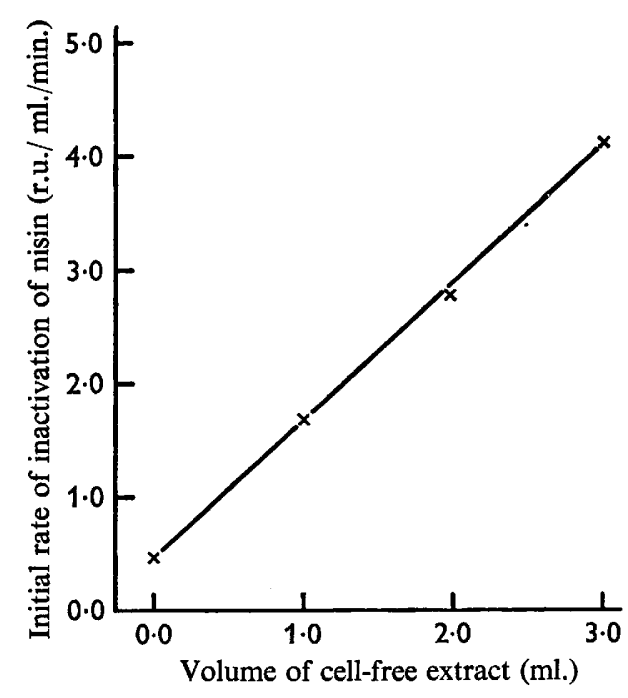

Fig. 4

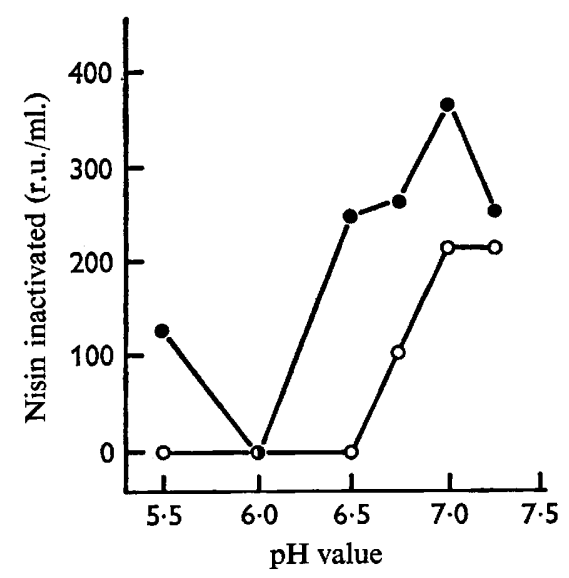

Fig. 5

Fig. 4. The effect of volume of enzyme preparation on the initial rate of inactivation of nisin by cell-free extract of Bacillus polymyxa. Initial rates of inactivation of nisin were obtained from results presented in Fig. 3 by constructing the tangent to the reaction curve at time $0 \mathrm{hr}$. and determining the slope of the tangent. The rate of inactivation of nisin was calculated in terms of r.u. nisin inactivated $/ \mathrm{ml}$. reaction mixture $/ \mathrm{min}$.

Fig. 5. The effect of $\mathrm{pH}$ on the enzymic inactivation of nisin by cell-free extracts of Bacillus cereus and B. polymyxa. Reaction mixtures consisted of $2.0 \mathrm{ml}$. buffered $(\mathrm{pH} \mathrm{7.0)}$ cell-free extract of Bacillus cereus (O-O) or B. polymyxa (-), $1.0 \mathrm{ml}$. of a solution of nisin $(5000 \mathrm{r}$.u. $/ \mathrm{ml}$. $0.02 \mathrm{~N}-\mathrm{HCl})$ and $6.0 \mathrm{ml}$. of Mcllvaine's buffer $(0.1 \mathrm{M}$-citric acid $+0.2 \mathrm{M}$ $\mathrm{Na}_{2} \mathrm{HPO}_{4}$ ). Controls were prepared from buffered substrate containing $2.0 \mathrm{ml}$. heatinactivated preparation. The $\mathrm{pH}$ levels of the reaction mixtures were determined on the incubated mixtures. Aliquots $\left(0.9 \mathrm{ml}\right.$.) were removed before and after incubation at $30^{\circ}$ for $6 \mathrm{hr}$ and pipetted into $0.1 \mathrm{ml} .2 \mathrm{~N}-\mathrm{HCl}$. After heating for $5 \mathrm{~min}$. at $100^{\circ}$, the samples were diluted in $0.02 \mathrm{~N}-\mathrm{HCl}$ for assay of residual nisin. The results presented allow for inactivation of nisin (c. $10 \%)$ in the controls.

Extracts of both Bacillus cereus and B. polymyxa exhibited optimal activity around pH 7.0 (Fig. 5), but it was not possible to assess the activity under alkaline conditions since nisin is chemically inactivated under these conditions. There appeared to be a secondary optimum below $\mathrm{pH} 6.0$ with the extract from $B$. polymyxa. 
A preliminary investigation of the effect of enzyme inhibitors and cations on the activity of the extracts showed that both preparations required the presence of $\mathrm{Ca}^{2+}$, $\mathrm{Co}^{2+}$ and $\mathrm{Mg}^{2+}$ for maximal activity. Activity was decreased after prolonged dialysis against distilled water or buffer $(\mathrm{pH} 7.0)$ and was restored by adding these cations (Table 5). No differences were observed in the degree of activity of the preparations dialysed against water and those dialysed against isomolar buffer. This shows that the requirement for certain cations was not a function of the complexing effect of the citrate in the McIlvaine buffer. The enzymic destruction of nisin was inhibited to various degrees by the presence of $\mathrm{Zn}^{2+}, \mathrm{Fe}^{2+}, \mathrm{Cu}^{2+}$ and $\mathrm{Mn}^{2+}$ and by EDTA, KCN, cysteine, GSH and $p$-chloromercuribenzoate (Table 6). Inhibition by EDTA confirmed the requirement for certain cations; whilst both cysteine and GSH caused a marked decrease in anti-nisin activity, both reagents themselves caused partial inactivation of the substrate. The effect of iodoacetate and of $\mathrm{Hg}^{2+}$ could not be determined since the former resulted in total inactivation of the nisin and the latter was toxic to the test organism.

Table 5. The effect of added cations on the anti-nisin activity of dialysed cellfree extracts of Bacillus cereus (NCIB 3329) and B. polymyxa

Cell-free extracts were dialysed at $2^{\circ}$ for $48 \mathrm{hr}$ against distilled water. Reaction mixtures consisted of $1.0 \mathrm{ml}$. dialysed enzyme preparation, $0.5 \mathrm{ml}$. nisin solution $(5,000 \mathrm{r} . \mathrm{u} . / \mathrm{ml}$.), $0.5 \mathrm{ml}$. of each cation solution (to $0.1 \mathrm{~mm}$ where appropriate) and Mcllvaine buffer ( $\mathrm{pH} 7.0$ ) to $4.5 \mathrm{ml}$. Samples $(0.9 \mathrm{ml}$.) were taken immediately after mixing the reagents and after incubation for $6 \mathrm{hr}$ at $30^{\circ}$, and were pipetted into $0.1 \mathrm{ml}$. $2 \mathrm{~N}-\mathrm{HCl}$. The acidified samples were heated for $5 \mathrm{~min}$. at $100^{\circ}$ and were diluted in $0.02 \mathrm{~N}-\mathrm{HCl}$ for assay of residual nisin.

r.u. nisin inactivated by $0.2 \mathrm{ml}$. enzyme preparation of

Enzyme preparation

Dialysis residue alone

Dialysis residue $+\mathrm{Ca}^{2+}$

Dialysis residue $+\mathrm{Mg}^{2+}$

Dialysis residue $+\mathrm{Co}^{2+}$

Dialysis residue $+\mathrm{Ca}^{2+}+\mathrm{Mg}^{2+}$

Dialysis residue $+\mathrm{Ca}^{2+}+\mathrm{Co}^{2+}$

Dialysis residue $+\mathrm{Mg}^{2+}+\mathrm{Co}^{2+}$

Dialysis residue $+\mathrm{Ca}^{2+}+\mathrm{Mg}^{2+}+\mathrm{Co}^{2+}$

$\begin{array}{cc}\text { B. polymyxa } & \text { B. cereus } \\ 215 & 45 \\ 355 & 195 \\ 317 & 135 \\ 240 & 120 \\ 413 & 255 \\ 437 & 339 \\ 427 & 291 \\ 401 & 307\end{array}$

\section{Specificity of the anti-nisin enzymes}

The cell-free preparations from vegetative Bacillus cereus and B. polymyxa had no observable effect against casein, gelatin or bovine serum albumin, and neither caused coagulation of skim milk at $\mathrm{pH} 6.0$ or $\mathrm{pH} 7 \cdot 0$. From these results it is inferred that the nisin-inactivating enzymes are not proteases. The preparations were unable to decrease the potency against Micrococcus flavus of the polypeptide antibiotics bacitracin or polymixin B and destruction of gramicidin could not be shown. However, the anti-nisin preparations were active against subtilin and resulted in marked inactivation. 


\title{
Electrophoresis of preparations from vegetative Bacillus cereus and B. polymyxa
}

The electrophoretic patterns produced on cellulose acetate were similar for extracts of both Bacillus cereus and B. polymyxa. The best separation was obtained with tris-

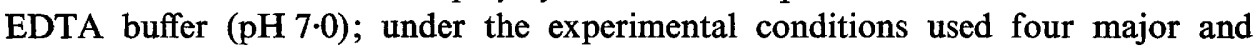
several minor fractions were observed. No attempt has yet been made to determine whether more than one of these fractions is active against nisin.

Table 6. The effect of inhibitors on the anti-nisin activity of cell-free extracts of Bacillus cereus and B. polymyxa

\begin{abstract}
Reaction mixtures consisted of $1.0 \mathrm{ml}$. enzyme preparation, $0.5 \mathrm{ml}$. nisin solution (5000 r.u./ml.), $0.5 \mathrm{ml}$. inhibitor solution and McIlvaine buffer ( $\mathrm{pH} 7.0$ ) to $4.5 \mathrm{ml}$. Samples $\left(0.9 \mathrm{ml}\right.$.) were taken immediately after mixing the reagents and after $6 \mathrm{hr}$ incubation at $30^{\circ}$, and were pipetted into $0.1 \mathrm{ml}$. $2 \mathrm{~N}-\mathrm{HCl}$. The acidified samples were heated for $5 \mathrm{~min}$. at $100^{\circ}$ and were diluted in $0.02 \mathrm{~N}-\mathrm{HCl}$ for assay of residual nisin.
\end{abstract}

\begin{tabular}{|c|c|c|c|}
\hline \multirow[b]{2}{*}{ Inhibitor } & \multirow{2}{*}{$\begin{array}{l}\text { Concentration } \\
\text { of inhibitor } \\
\text { (mM) }\end{array}$} & \multicolumn{2}{|c|}{$\begin{array}{l}\text { r.u. nisin inactivated by } 0.2 \mathrm{ml} \text {. } \\
\text { enzyme preparation of }\end{array}$} \\
\hline & & B. polymyxa & B. cereus \\
\hline None & - & 350 & 182 \\
\hline $\mathrm{Mn}^{2+}$ & $0 \cdot 1$ & 308 & 151 \\
\hline $\mathrm{Zn}^{2+}$ & $1 \cdot 0$ & 245 & 125 \\
\hline $\mathrm{Fe}^{2+}$ & $1 \cdot 0$ & 25 & 0 \\
\hline $\mathrm{Cu}^{2+}$ & 1.0 & 0 & 10 \\
\hline EDTA & $1 \cdot 0$ & 60 & 0 \\
\hline $\mathrm{KCN}$ & 1.0 & 0 & 93 \\
\hline $\begin{array}{l}p \text {-Chloromercuri- } \\
\text { benzoate }\end{array}$ & $1 \cdot 0$ & 280 & 132 \\
\hline Cysteine & $1 \cdot 0$ & 12 & 0 \\
\hline GSH & $1 \cdot 0$ & 69 & 71 \\
\hline
\end{tabular}

\section{DISCUSSION}

Three general modes of resistance to antibiotics have been described. The first of these is the production of an enzyme capable of destroying the antibiotic, as in the case of penicillinase (Bondi \& Dietz, 1948; Pollock, 1957) and nisinase (Alifax \& Chevalier, 1962). The second mode of resistance is due to changes in the cell-wall permeability, e.g. resistance to chloramphenicol (Kushner, 1955) and actinomycin (Polsinelli et al. 1964). The third type is the acquisistion of some other mechanism (e.g. modification of the antibiotic-binding capacity of DNA) as reported for chlortetracycline (Saz \& Martinez, 1956) and erythromycin (Taubman, Young \& Corcoran, 1963).

The production of nisin-inactivating enzymes by certain species of the genus Bacillus ( $B$. cereus, $B$. cereus var. mycoides, $B$. polymyxa, B. megaterium) suggests that the mechanism of resistance to nisin by these organisms is dependent upon enzymic destruction of the nisin. Whilst nisin produces inhibition at all stages of growth the effect is more pronounced during the early phases when no intracellular anti-nisin enzyme is detectable. This suggests that the resistance of mature vegetative forms and of endospores of these species may be linked to production of the enzyme. However, since young organisms were able to overcome the inhibitory effect of nisin, the mode 
of resistance may be unrelated to the mechanism for production of the enzyme. It is possible that the enzyme is produced by the mature vegetative organisms for some function other than inactivation of nisin; however, the function of the enzyme would appear to differ from that of the lytic enzymes previously described (Strange \& Dark, $1957 a, b)$.

Since the vegetative forms of the Bacillus species examined (except B. stearothermophilus) were resistant to similar concentrations of nisin, it appears that a general mechanism of resistance other than production of nisin-inactivating enzyme is prevalent within the genus. It is possible that the anti-nisin enzyme is produced by the sporulating organism and then adsorbed on to, or combined with, the wall of the type $\mathrm{L}$ endospore. This would explain the observation that type $\mathrm{L}$ endospores, which contain an extractable nisin-inactivating enzyme, are more resistant to nisin than are type M endospores (Gould \& Hurst, 1962; Gould, 1964).

It has been reported that nisin is inactivated by treatment with trypsin (Thorpe, 1960) and pancreatin (Heinemann \& Williams, 1966). It is not surprising therefore that 'subtilopeptidase' also causes inactivation. However the extracellular proteases from several other Bacillus species appear to be unable to inactivate nisin; this suggests that these enzymes may have a mode of action which differs from that of tryptic-type of enzyme.

The relative decrease of the yield of organisms when cultivated in the presence of nisin is a direct result of nisin-induced lysis and of the secondary lag phase, since in the experiments made nisin was added to cultures in the logarithmic phase and the organisms were harvested after the same total incubation period as organisms grown in the absence of nisin. Furthermore, the lower specific activity of extracts obtained from organisms grown in medium containing nisin, resulted from the secondary lag phase. At the time of harvesting the organisms would be in a relatively less mature state and would have produced less enzyme than those organisms growing in nisin-free medium. The observed decrease in the specific activity of the extracts is consistent with these conclusions.

The results obtained in this work suggest that the anti-nisin action of cell-free extracts of Bacillus cereus and $\dot{B}$. polymyxa is due to enzymic activity. Although the tests of substrate specificity were limited, activity was observed only against nisin and subtilin. Both of these polypeptides contain the S-amino acids $\beta$-methyllanthionine and lanthionine in the ratio of 4:1 (Lewis \& Snell, 1951; Newton, Abraham \& Berridge, 1953), although Cheeseman \& Berridge (1959) have since shown a ratio of $3: 1$ in nisin A. However, the antibiotics differ in their content of other amino acids (Berridge, Newton \& Abraham, 1952; Lewis \& Snell, 1951; Cheeseman \& Berridge, 1959). In view of the similarity in the S-amino acid composition of nisin and subtilin it is possible that lanthionine and $\beta$-methylanthionine form part of the active centre of the antibiotics and that the enzyme acts by disrupting this structure.

The properties of the nisin-inactivating enzymes of Bacillus cereus and B. polymyxa appear to be similar, but no similarities exist between the properties of the nisininactivating enzyme of $B$. cereus and the extracellular protease of this organism described by Salter (1959). The crude cell-free extracts of vegetative forms of $B$. cereus and $B$. polymyxa contain at least seven protein components. 
I am indebted to Dr N. J. Berridge of N.I.R.D., Shinfield, for advice and helpful discussions. I should also like to thank Professor B. C. J. G. Knight and Dr H. Fore for their comments on the manuscript. I am grateful to Messrs Aplin and Barrett, Ltd., Trowbridge, Wilts., for supplies of Nisaplin and of purified nisin, to Dr J. C. Lewis for the gift of subtilin and to Dr G. W. Gould for a culture of Bacillus cereus (PX).

\section{REFERENCES}

Alifax, R. \& Chevalier, R. (1962). Study of the nisinase produced by Streptococcus thermophilus. J. Dairy Res. 29, 233.

BerRidge, N. J. (1949). Preparation of the antibiotic nisin. Biochem. J. 45, 486.

Berridge, N. J., Newton, G. G. F. \& Abraham, E. P. (1952). Purification and nature of the antibiotic nisin. Biochem. J. 52, 529.

Bondi, A. \& DieTZ, C. C. (1948). The susceptibility of penicillinase producing bacteria to penicillin. J. Bact. 55, 843 .

CARLSON, S. \& BAUER, H. M. (1957). A study of problems associated with resistance to nisin, an antibiotic produced by Streptococcus lactis. Arch. Hyg. Bakt. 141, 445.

Cheeseman, G. C. \& BerRidge, N. J. (1959). Observations on the molecular weight and chemical composition of nisin A. Biochem. J. 71, 185.

GalesLOot, Tн. E. (1956). Lactic acid bacteria which destroy the antibiotic nisin. Ned. Melk-en Zuiveltijdschr. 10, 143.

GouLd, G. W. (1964). Effect of food preservatives on the growth of bacteria from spores. Proc. 4th int. Symp. Food Microbiol. Göteborg, Sweden, 17.

Gould, G. W. \& HITCHINs, A. D. (1965). Germination of spores with Strange \& Dark's lytic enzyme. In Spores, 3, 213. ed. by L. L. Campbell and H. O. Halvorson. Published by Amer. Soc. Microbiol.

Gould, G. W. \& HuRsT, A. (1962). Inhibition of Bacillus spore development by nisin and subtilin. 8th int. Congr. Microbiol. Abstracts, A2-11.

Gunsalus, I. C. (1954). Extraction of enzymes from micro-organisms. Meth. Enzymol. 1, 51.

GüNTELBerg, A. V. \& OTtesen, M. (1952). Preparation of crystals containing the plakalbuminforming enzyme from Bacillus subtilis. Nature, Lond. 170, 802.

Heinemann, B. \& Williams, R. (1966). Inactivation of nisin by pancreatin. J. Dairy Sci. 49, 312.

JARVIS, B. (1966). Technique for measurement of antibiotic inhibition zones. J. Dairy Sci. 49, 318.

KoнN, J. (1958). A microelectrophoretic technique. Nature, Lond. 180, 39.

KUSHNER, D. J. (1955). The basis of chloramphenicol resistance in Pseudomonas fluorescens. Arch. Biochem. Biophys. 58, 347.

LewIS, J. C. \& SNELL, N. S. (1951). The amino acid composition of subtilin. J. Am. chem. Soc. 73, 4812.

LiPINSKa, E. \& StrZalKowSKa, M. (1959). Experiments on training pure cheese cultures to resist antibiotics produced by Streptococcus lactis. Proc. 15th int. Dairy Congr. 2, 572.

McIlvaine, T. C. (1921). A buffer solution for colorimetric comparison. J. biol. Chem. 49, 183.

Newton, G. G. F., Abraham, E. P. \& Berridge, N. J. (1953). Sulphur-containing amino acids of nisin. Nature, Lond. 171, 606.

Pollock, M. R. (1957). Penicillin-induced resistance to penicillin in cultures of B. cereus. In Drug Resistance in Micro-organisms. Ed. by G. E. W. Wolstenholme and E. C. O'Connor, p. 78, London: Churchill.

Polsinelli, M., Ciferri, O., Cassani, G. \& Albertini, A. (1964). Mechanism of resistance to actinomycin in B. subtilis. J. Bact. 88, 1567.

RAMSEIER, H. R. (1960). The action of nisin on Clostridium butyricum. Archiv. Mikrobiol. 37, 57.

Report of the Commission on Enzymes of the International Union of Biochemistry (1961) Oxford: Pergamon.

SACKS, S. E. (1955). The tryptic digestion of subtilin. Bact. Proc. A 37, 30.

SALTER, D. N. (1959). Purification and properties of a proteinase from B. cereus NCTC 945. Biochem.J. $72,23 \mathrm{p}$.

Salton, M. R. J. \& HoRNe, R. W. (1951). Studies of the bacterial cell wall. II. Methods of preparation and some properties of cell walls. Biochim. biophys. Acta 7, 177.

SAZ, A. K. \& MARTinez, L. M. (1956). Enzymatic basis of resistance to aureomycin. I. Difference between flavoprotein nitro-reductase of sensitive and resistant Escherichia coli. J. biol. Chem. 223, 285.

SMITH, I. (1960). Chromatographic and Electrophoretic Techniques, 2nd edn. Vol. 2. Zone Electrophoresis. London: Heinemann. 
SMITH, N. R., Gordon, R. E. \& ClaRK, E. E. (1952). Aerobic sporeforming bacteria. U.S.D.A. Agricultural Monograph, no. 16.

Strange, R. E. \& Dark, F. A. (1957a). A cell-wall lytic enzyme associated with spores of Bacillus species. J. gen. Microbiol. 16, 236.

StRANGE, R. E. \& DARK, F. A. (1957b). Cell-wall lytic enzymes at sporulation and germination in Bacillus species. J. gen. Microbiol. 17, 525.

Taubman, S. B., Young, F. E. \& Corcoran, J. W. (1963). Antibiotic glycosides IV. Studies on the mechanism of erythromycin resistance in B. subtilis. Proc. natn. Acad. Sci. U.S.A. 50, 955.

THORPE, R. H. (1960). The action of nisin on spoilage bacteria I. The effect of nisin on the heat resistance of Bacillus stearothermophilus. J. appl. Bact. 23, 136.

TRAMER, J. \& Fowler, G. G. (1964). Estimation of nisin in foods. J. Sci. Fd. Agric. 15, 522. 